\title{
Kualitas Pelayanan Staf Front Office Hotel di Bali
}

\author{
Indah Kusumarini
}

Manajemen Konvensi Perhelatan, Politeknik Pariwisata Bali

Jl. Darmawangsa, Kampial, Kuta Selatan, Badung, Bali

indahnusabakti@gmail.com

Received: Oktober, $2021 \quad$ Accepted: Oktober, 2021

Published: Desember, 2021

\begin{abstract}
This reseach was conducted by using the theory of service quality dimensions from ZeithamlParasuraman-Berry (1996). Data obtained by distributing 100 questionnaires to Japanese tourists on August 2019. The variable created refers to the role of the front office clerk from Bagiono (2012). Based on SPSS calculations, the accuracy of this research model is $73 \%$ at an error rate of 5\%. From the results of data processing it is known that the average value of the service quality of front office staff at star hotels in Bali is 4.11 (good). But there are still indicators that are not good, that is, an indicator of Japanese language ability, with an average value of 3.23. Based on the results of exploratory factor analysis of 31 variables, found 7 factors forming the quality of front office staff services, 1) responsiveness with a value $(13,916), 2)$ empathy $(2,355), 3)$ reliability $(1,513), 4)$ tangible $(1,486), 5)$ assurance $(1.29), 6)$ friendly $(1,220)$, and 7$)$ communication $(1,140)$. The biggest factor influencing the satisfaction of Japanese tourists towards the quality of front office staff services is the responsiveness factor while the lowest factor is the communication factor.
\end{abstract}

Keywords: quality service, front office hotel staff

\section{Abstrak}

Penelitian ini menggunakan teori dimensi kualitas pelayanan dari Zeithaml-ParasuramanBerry (1996). Data diperoleh dengan cara menyebarkan 100 angket kepada wisatawan Jepang pada bulan Agustus 2019. Berdasarkan penghitungan SPSS, ketepatan model penelitian ini sebesar 73\% pada tingkat kesalahan sebesar 5\% . Dari hasil pengolahan data diketahui nilai rata-rata kualitas pelayanan staf front office hotel sebesar 4,11 (bagus). Namun masih terdapat indikator yang kurang bagus yaitu pada indikator kemampuan berbahasa Jepang, dengan nilai rata-rata 3,23. Berdasarkan hasil analisis faktor exploratori terhadap 31 variabel, ditemukan 7 faktor pembentuk kualitas pelayanan staf front office, yaitu: 1) responsiveness dengan nilai $(13,916), 2)$ empathy $(2,355), 3)$ reliability $(1,513), 4)$ tangible(1,486), 5) assurance $(1,29), 6)$ friendly $(1,220)$, dan 7) communication $(1,140)$. Dari 7 faktor tersebut, faktor yang paling besar memengaruhi kepuasan wisatawan Jepang terhadap kualitas pelayanan staf front office adalah faktor Daya tanggap(responsiveness) sedangkan faktor terendah adalah faktor komunikasi sehingga faktor komunikasi perlu mendapat perhatian guna meningkatkan kualitas pelayanan terhadap tamu Jepang.

Kata kunci: kualitas pelayanan, staf front office 


\section{PENDAHULUAN}

Bali sebagai salah satu destinasi pariwisata dunia, dikenal keindahan alam dan budayanya. Dengan dikelilingi pantai, kehidupan masyarakatnya dalam balutan adat istiadat yang khas, menjadikan Bali memiliki daya tarik tersendiri bagi wisatawan mancanegara dan juga wisatawan lokal. Prestasi pariwisata Indonesia dapat dilihat dari penghargaan dunia yang telah diraih. Pada tahun 2017 dinobatka sebagai " Destination of the Year" dalam ajang The 28th Annual TTG (Travel Trade Gazette) Travel Award di Bangkok, 28 September 2017. Video promosi pariwisata Indonesia "The Journey of a Wonderful World" memenangkan juara tingkat Asia Pasifik pada ajang kompetisi yang diselenggarakan UNWTO (United Nations World Tourism Organization) di China pada tanggal 15 September 2017.

Pada tahun 2018, Bali berhasil menyabet 3 penghargaan dunia dalam Global destination Marketing Summit and World Culture and Tourism Forum di Tiongkok, menyabet 3 kategori award sekaligus, yakni Top 10 Overseas Destination, Top 10 Luxury Travel Destination, dan Top 10 Honeymoon Destination for Chinese Tourists selama tahun 2017. Untuk Honeymoon Destination, Bali berada pada urutan teratas, mengalahkan Hawai, Paris, New York, Dubai, Madrid, Sidney dan Guam. Untuk kategori Top 10 Overseas Destination dan Top 10 Luxury Travel Destination, Bali menduduki urutan ke-empat.

Selain alam dan budaya, akomodasi juga merupakan salah satu daya tarik wisata Bali. Pada tahun 2018, dari 100 hotel di dunia, lima hotel dari Indonesia mendapat penghargaan tingkat dunia. Hotel tersebut adalah hotel the Mulia Bali, Nihi-Sumba, Amandari Bali dan Alila Manggis. Hotel Four Seasons resort Bali di Sayan menduduki urutan teratas sebagai hotel terbaik dunia pada tahun 2018.(kompas.com, Denpasar, 13 Juli 2018)

Berdasarkan data dari Buku Cetak Biru-Kemenpar 2016 dan hasil wawancara dengan pihak Travel Agent Jepang di Bali, yaitu JTB Travel pada bulan Desember 2018, diketahui sebagian besar(74\%) wisatawan Jepang memilih paket Tur dengan standard hotel berbintang, luxury hotel atau villa yang rata-rata haarga kamar per malam 2-3 juta(standard room) hingga puluhan juta, tergantung jenis kamar dan jika saat peak season harga bisa naik 50\%. Sebagian besar tamu Jepang memilih hotel di Nusa Dua kawasan Indonesia Tourism Development Corporation (ITDC), Jimbaran dan Ubud. Hotelhotel yang merupakan favorit wisatawan Jepang antara lain adalah hotel Grant Hyatt-Nusa Dua, Melia, Ayana-Nusadua, Seraton Laguna, Novotel Nusa Dua, Mulia, Conrad, RitzCarlton, Four Seasons-Jimbaran, Water Mark-Jimbaran, Bali Padma-Legian, MayaUbud, Hoshinoya-Ubud dan lain-lain.

Wisatawan Jepang merupakan wisatawan potensial. Rata-rata lama tinggal wisatawan Jepang adalah 5 hari 4 malam. Spending money rata-rata Rp.11,19 juta/orang. Jika dibandingkan dengan wisatawan asal China yang sedang booming sekarang ini, jauh memberikan kontribusi yang besar terhadap pendapatan negara dari sektor pariwisata. Rata-rata pengeluaran wisatawan China, Rp. 9,66 juta/orang. Lebih rendah dari pengeluaran wisatawan dari Australia, Eropa dan Jepang. Pengeluaran wisatawan Australia rata-rata 13,4 juta/orang(bisnis.com.Denpasar. 22 Oktober 2018).

Saat ini kunjungan wisman ke Bali lebih banyak didominasi wisatawan asal China, India dan Australia. Jepang berada pada peringkat ke-7, dibawah Inggris dan Amerika. Kunjungan wisatawan Jepang dari tahun 90 an hingga tahun 2000, tergolong tinggi dan selalu berada di urutan pertama atau kedua bergantian dengan wisatawan asal Australia. Terjadi penurunan pada tahun 2002 dan 2004 , namun perlahan kunjungan wisman asal Jepang meningkat kembali, di angka 400 ribuan hingga tahun 2008. Penurunan kunjungan wisatawan Jepang terulang kembali pada tahun 2009. Dari 333.905 orang turun $26,61 \%$ menjadi 246.465 orang pada tahun 2010. Semakin turun pada tahun 2011 yaitu 183.284, rentetan dari efek bencana tsunami di Jepang pada bulan Maret 2011 di negara Jepang. Tingkat kunjungan wisatawan Jepang ke Bali mulai terlihat meningkat pada tahun 2013, 
walaupun tidak begitu besar, masih di angka 200.000 an hingga tahun 2019, diangka 280.000 seperti terlihat di grafik ini.

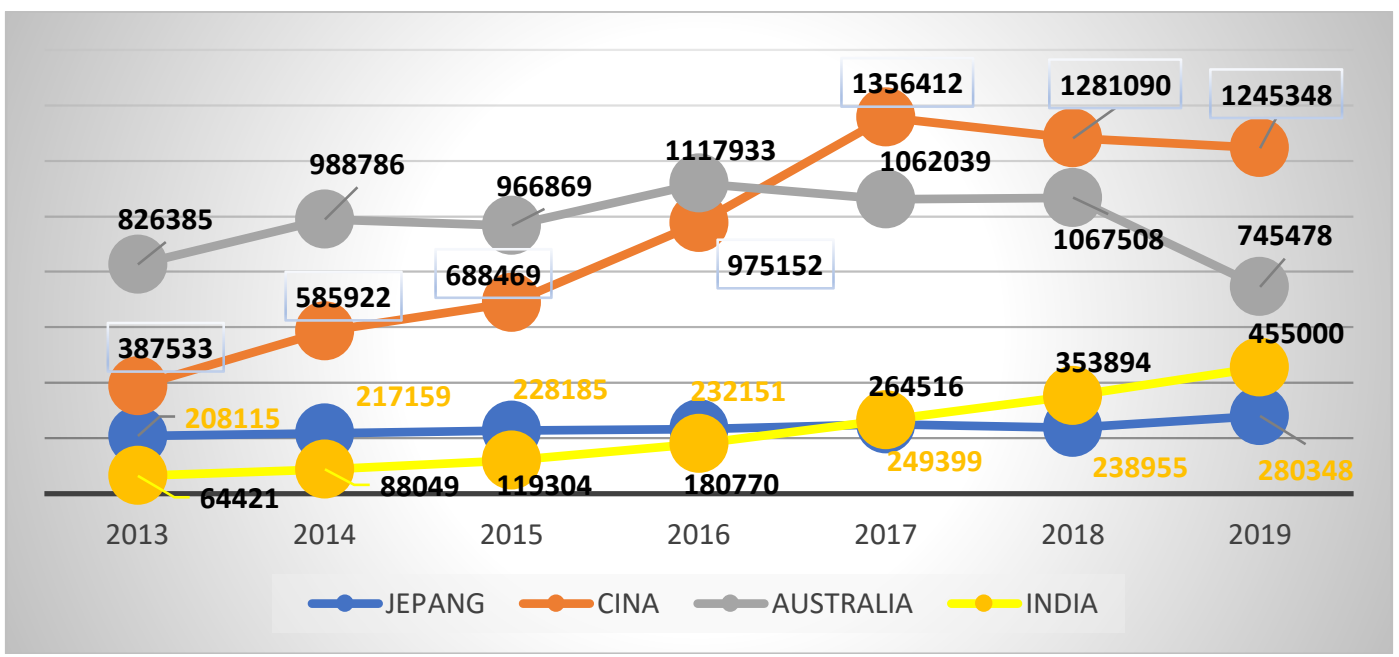

Gambar 1. Kunjungan Wisatawan Jepang ke Bali

[Sumber: Badan Pusat Statistik, Propinsi Bali 2019]

Dengan melihat kecenderungan tingkat kunjungan wisman Jepang yang rendah, maka perlu dilakukan upaya menggaet wisatawan Jepang mengingat potensi wisatawan Jepang dengan spending moneynya yang tinggi. Satu hal dari karakter wisatan Jepang adalah loyalitas. Artinya jika mendapatkan kesan memuaskan saat menginap di suatu hotel, dia akan datang lagi sebagai repeater di hotel tersebut. Seperti terlihat di hotel Padma Resort Bali dimana kebanyakan adalah tamu repeater. Sebagian besar tamu Jepang (47\%) mendapatkan informasi dari teman atau kerabat (word of mouth). Artinya rekomendasi dari orang yang dikenal masih merupakan prioritas bagi orang Jepang untuk mengambil keputusan mengunjungi suatu destinasi wisata.

Oleh karena itu perlu dilakukan penelitian sebagai upaya untuk meningkatkan jumlah kunjungan wisatawan jepang, melalu peningkatan kualitas pelayanan. Dengan peningkatan kualitas pelayanan, maka diharapkan wisatawan akan merasa puas. Terjaganya kepuasan wisatawan, secara tidak langsung akan berdampak pada reputasi positif bagi daerah tujuan wisata. Dan ini menjadi daya tarik bagi calon wisatawan dalam mengambil keputusan untuk mengunjungi suatu daerah tujuan wisata. Begitu juga dengan Bali, jika reputasi destinasi wisata Bali dipandang baik dimata dunia, maka wisatawan akan banyak berkunjung ke Bali dan melakukan kunjungan ulang dimasa mendatang.

Kualitas pelayanan merupakan segala bentuk aktivitas yang dilakukan oleh perusahaan guna memenuhi harapan konsumen. Pelayanan sebagai jasa atau service disampaikan oleh pemilik jasa berupa kemudahan, kecepatan, hubungan, kemampuan dan keramahtamahan, ditujukan untuk kepuasan konsumen. (Kotler, 2013:37)

Parasuraman, Zeithaml \& Berry (1996) menjelaskan bahwa kualitas pelayanan dapat dilihat dari segi 1) reliability (dapat memberikan pelayanan yang handal, akurat, terpercaya), 2)responsiveness (daya tanggap), 3)assurance (jaminan pelayanan yang baik,sopan, ramah), 4)empathy (komunikasi yang baik, mampu memahami keinginan konsumen), 5) tangible (tampilan fisik layanan seperti grooming).

Toeri ini dijadikan pisau bedah untuk menganalisa kualitas pelayanan staf kantor depan hotel berbintang di Bali, khususnya terhadap tamu Jepang.

Kantor depan merupakan bagian dari departemen di hotel yang mempunyai intensitas tinggi bertemu dengan tamu. Tamu pertama masuk ke hotel, pasti yang dituju 
pertama kali adalah bagian kantor depan. Sehingga kantor depan dapat dikatakan menjadi image atau mewakili wajah dari suatu hotel.

Menurut Bagyono (2012:44) departemen front office memiliki fungsi-fungsi penting dalam penyelenggaraan hotel secara menyeluruh, yaitu 1) menjual kamar (reservasi, check-in dan check out), 2) menangani informasi tentang produk dan layanan didalam hotel dan fasilitas umum segala sesuatu berkaitan dengan obyek dan atraksi wisata 3) mengkoordinasi pelayanan tamu, 4) melaporkan status kamar, 5) mencatat pembayaran tamu, 6) menyusun riwayat kunjungan tamu.7) menangani layanan komunikasi melalui telepon, 8) menangani barang bawaan tamu.

Penelitian terkait kualitas pelayanan staf front office telah dilakukan oleh Nurhidayah (2017), yang berjudul "Kualitas Pelayanan Front Office Departement Syariah Hotel Solo Terhadap Tingkat Kepuasan Tamu Individual “. Hasil penelitiannya menunjukkan bahwa variabel yang paling dominan mempengaruhi tingkat kepuasan tamu individual adalah variabel emphaty. Variabel ini memiliki tingkat koefisien regresi yang paling tinggi yakni 1.162. Sedangkan variabel yang kurang memberikan kontribusi terhadap tingkat kepuasan tamu individual adalah variabel reliability dengan tingkat koefisien regresi yang paling rendah yakni -0.673 .

Penelitian sejenis telah dilakukan Alan (2016), berjudul "Pengaruh Service Quality terhadap Customer Satisfaction di Hotel Serela Bandung". Hasil penelitiannya menunjukkan bahwa terdapat pengaruh service quality terhadap customer satisfaction di Hotel Serela Bandung dengan besar pengaruh 35.80\%. Dimensi“tangible" berpengaruh terhadap customer satisfaction dengan besar pengaruh 30.25\%. Dimensi "empathy" berpengaruh terhadap customer dengan besar pengaruh $26.41 \%$. Sedangkan dimensi reliability, responsibility dan assurance, tidak berpengaruh terhadap customer satisfaction di Hotel Serela Bandung.

Kedua penelitian tersebut menggunakan rumus ServQual $\quad \mathbf{S}=\mathbf{f}(\mathbf{P}, \mathbf{E})$ namun pada penelitian ini digunakan analisis faktor eksploratori untuk menemukan faktor yang mempengaruhi kualiatas pelayanan staf front office hotel di Bali. Sehingga rumusan masalah dalam penelitian ini adalah:

1) Bagaimana kualitas pelayanan staf front office hotel di Bali?

2) Faktor apa yang mempengaruhi kualitas pelayanan staf hotel di Bali?

3) Faktor pelayanan apa yang paling kurang memuaskan tamu Jepang?

\section{METODE PENELITIAN}

Penelitian ini merupakan penelitian deskriptif kualitatif, yang bertujuan untuk mendeskripsikan kualitas pelayanan staf front office hotel di Bali terhadap wisatawan Jepang.

Teori kualitas pelayanan dari Parasuraman (1996) menjadi pisau bedah penelitian ini, yaitu lima dimensi pelayanan yang terdiri dari dimensi 1) responsiveness, 2) empathy 3) reliability, 4) tangible, 5) assurance .

Data diperoleh dengan cara menyebarkan 100 angket kepada wisatawan Jepang di bandara Ngurah Rai Bali kususnya di international departure pada bulan Agustus 2019. Variabel dibuat merujuk pada peran petugas front office dari Bagiono (2012), sehingga digunakan 31 variabel untuk mengukur kualitas pelayanan staf front office hotel di Bali

Analisis data digunakan analisis faktor Ekploratori terhadap 31 variabel (indikator pengukuran) untuk mengetahui faktor-faktor yang menentukan kualitas pelayanan staf front office hotel.

\subsection{Indikator}

Untuk mengukur kualitas pelayanan petugas front office hotel, digunakan indikator pengukuran yang terdiri dari 31 variabel, seperti di bawah ini. 
Tabel 1; Indikator Kualitas Pelayanan Petugas Front Office Hotel di Bali terhadap Wisatawan Jepang

[Sumber : Modifikasi Tjiptono (1996:71)]

\begin{tabular}{|c|c|}
\hline DIMENSI PELAYANAN & INDIKATOR/ASPEK PELAYANAN \\
\hline TANGIBLE ( Bukti & Penampilan bersih dan rapi \\
\hline \multirow[t]{7}{*}{ /wujud Langsung) } & Memakai Name tag. \\
\hline & Seragam bersih dan menarik \\
\hline & Wajah cantik/tampan dan menarik \\
\hline & Wajah tersenyum \\
\hline & Sikap tubuh yang sopan \\
\hline & Sikap tubuh yang sopan dan menunjukkan kesungguhan, \\
\hline & ketulusan melayani tamu \\
\hline \multirow[t]{8}{*}{ Reliability (Keandalan) } & Mampu menjelaskan produk kamar hotel \\
\hline & $\begin{array}{l}\text { Mampu menjelaskan produk hotel, seperti restoran, spa dan lain- } \\
\text { lain. }\end{array}$ \\
\hline & Mampu memberikan pelayanan check in hotel \\
\hline & Mampu memberikan pelayanan check out hotel \\
\hline & mampu memberikan informasi fasilitas hotel \\
\hline & mampu memberikan informasi kepada tamu tentang tempat \\
\hline & Mampu Berbahasa Jepang \\
\hline & Mampu melakukan upselling kamar hotel \\
\hline \multirow{5}{*}{$\begin{array}{l}\text { Responsiveness (Daya } \\
\text { Tanggap) }\end{array}$} & Tanggap dalam menawarkan bantuan terhadap tamu \\
\hline & mengerjakan permintaan tamu secara cepat dan tepat \\
\hline & Melayani dengan cepat dan memuaskan \\
\hline & Menangani keluhan tamu secara efektif \\
\hline & $\begin{array}{l}\text { memiliki kemauan dan ketulusan untuk membantu, melayani } \\
\text { tamu }\end{array}$ \\
\hline \multirow[t]{5}{*}{ Assurance (Jaminan) } & pelayanan yang cepat dan memuaskan \\
\hline & kamar yang dipesan sesuai dengan yang ditawarkan. \\
\hline & Memberikan perasaan nyaman pada tamu hotel \\
\hline & Tidak diskriminasi terhadap tamu. Dari segi usia, kelamin, suku, \\
\hline & $\begin{array}{l}\text { Memberikan kepastian keamanan dan rasa nyaman selama tamu } \\
\text { menginap di hotel }\end{array}$ \\
\hline \multirow[t]{8}{*}{ Emphaty ( Empati ) } & memiliki kepekaan yang tinggi terhadap permasalahan tamu \\
\hline & memiliki kepekaan untuk menjaga rasa nyaman tamu \\
\hline & memiliki kepekaan terhadap budaya yang dimiliki tamu \\
\hline & memiliki kepekaan terhadap kebutuhan tamu \\
\hline & Menyapa Wisatawan dengan Nama \\
\hline & Mampu memberikan perhatian khusus kepada wisatawan \\
\hline & Mampu memberikan adivice kepada tamu \\
\hline & Akrab dan bersahabat dengan tamu \\
\hline
\end{tabular}

\subsection{Hasil Uji Validitas dan Reliabilitas}

Hasil uji validitas dan reliabilitas kuesioner penelitian menunjukkan bahwa semua variabel memiliki korelasi di atas 0,3 dan nilai koefisien Alpha Cronbach berada diatas 0,6 sehingga instrumen tersebut dinyatakan valid dan reliabel dan layak dijadikan instrumen penelitian.

Ketepatan model dapat diketahui dari besarnya residual yang terjadi. Residual adalah perbedaan korelasi yang diamati dan yang diproduksi berdasarkan estimasi matrik faktor. Pada penelitian ini besarnya persentase residual yang ditunjukkan adalah sebesar $27 \%$ atau sebanyak 130 residual atas dasar nilai absolut $>0,05$. Hal ini mengindikasikan 
bahwa model memiliki ketepatan model sebesar 73\% pada tingkat kesalahan sebesar 5\% atau dengan kata lain model dapat diterima dengan ketepatan $73 \%$.

Kriteria jumlah penilaian ada lima, yaitu sangat bagus (SB) dengan rentang nilai 5 , bagus (B) dengan rentang nilai 4, netral $(\mathrm{N})$ dengan rentang nilai 3, kurang Bagus (KB) dengan rentang nilai 2, dan sangat kurang bagus (SKB) dengan rentang nilai 1 . Menurut Sudjana (2007:56) kelas interval diukur dengan cara:

a)Menentukan score range(R) dengan cara Nilai terbesar dikurangi Nilai terkecil.

$\mathrm{R}=5-1=1$.

b)Menentukan interval Nilai, yaitu: $\frac{4}{5}=0.8$

c)Menentukan kelas interval, yaitu:

$1,0-1,7=$ sangat tidak bagus

$1,8-2,5=$ tidak bagus

$2,6-3,3=$ cukup

$3,4-4,1=$ bagus

$4,2-5,0=$ sangat bagus.

\section{HASIL DAN PEMBAHASAN}

\subsection{Deskripsi Data}

Dari 100 angket sebagai alat pengambilan data, diketahui responden perempuan sebanyak 51\% dan laki-laki sebanyak $49 \%$. Responden terbanyak adalah berumur 15-30 tahun, yaitu sebanyak $47 \%$, umur 31-45 sebanyak 32\% dan umur $>45$ tahun sebanyak $21 \%$. Berdasarkan pekerjaan responden terbanyak adalah pekerja swasta $71 \%$, PNS $10 \%$, bisnis $6 \%$ dan mahasiswa sebanyak 3\%. Berdasarkan tujuan ke Bali, terbanyak adalah untuk berwisata,78\%, bisnis $16 \%$ dan wedding sebanyak 6\%. Rata-rata lama tinggal sebagian besar kurang dari 5 hari, yaitu 92\%. Selama berlibur di Bali, menginap dihotel berbintang sebanyak $97 \%$ dan di homestay sebanyak $3 \%$.

\subsubsection{Kualitas Pelayanan Staf Front Office Hotel}

Kualitas pelayanan staf front office hotel dapat dlihat dari nilai rata-rata pada Tabel 2

Tabel 2; Kualitas Pelayanan Staf Front Office Hotel di Bali

\begin{tabular}{|c|c|c|c|c|c|c|c|}
\hline \multirow[b]{2}{*}{ Pernyataan } & \multicolumn{5}{|c|}{ Jawaban } & \multirow[b]{2}{*}{$\begin{array}{l}\text { Tota } \\
1\end{array}$} & \multirow[b]{2}{*}{ Mean } \\
\hline & SB & B & $\mathbf{N}$ & KB & $\begin{array}{r}\text { SK } \\
\text { B }\end{array}$ & & \\
\hline 1. Penampilan bersih dan rapi. & 52 & 34 & 13 & 0 & 1 & 436 & 4,36 \\
\hline 2. Memakai name tag & 42 & 32 & 24 & 2 & 0 & 414 & 4,14 \\
\hline 3. Seragam bersih dan menarik & 64 & 27 & 7 & 2 & 0 & 453 & 4,53 \\
\hline 4.Wajah selalu tersenyum ramah & 62 & 25 & 10 & 3 & 0 & 446 & 4,46 \\
\hline 5.Sikap tubuh yang sopan & 54 & 29 & 12 & 5 & 0 & 432 & 4,32 \\
\hline $\begin{array}{l}\text { 6.Mampu menjelaskan produk } \\
\text { kamar hotel }\end{array}$ & 28 & 37 & 28 & 5 & 2 & 384 & 3,84 \\
\hline $\begin{array}{l}\text { 7. Mampu menjelaskan produk hotel, } \\
\text { seperti restoran,spa dan lain-lain. }\end{array}$ & 40 & 35 & 20 & 5 & 0 & 410 & 4,10 \\
\hline $\begin{array}{l}\text { 8.Mampu memberikan pelayanan } \\
\text { saat check in hotel }\end{array}$ & 55 & 29 & 16 & 0 & 0 & 439 & 4,39 \\
\hline $\begin{array}{l}\text { 9.Mampu memberikan pelayanan } \\
\text { saat check outhotel }\end{array}$ & 57 & 26 & 17 & 0 & 0 & 440 & 4,4 \\
\hline $\begin{array}{l}\text { 10.Mampu memberikan informasi } \\
\text { fasilitas hotel }\end{array}$ & 44 & 28 & 25 & 3 & 0 & 413 & 4,13 \\
\hline 11.Mampu memberikan informasi & 30 & 32 & 30 & 6 & 2 & 382 & 3,82 \\
\hline
\end{tabular}


Indah Kusumarini

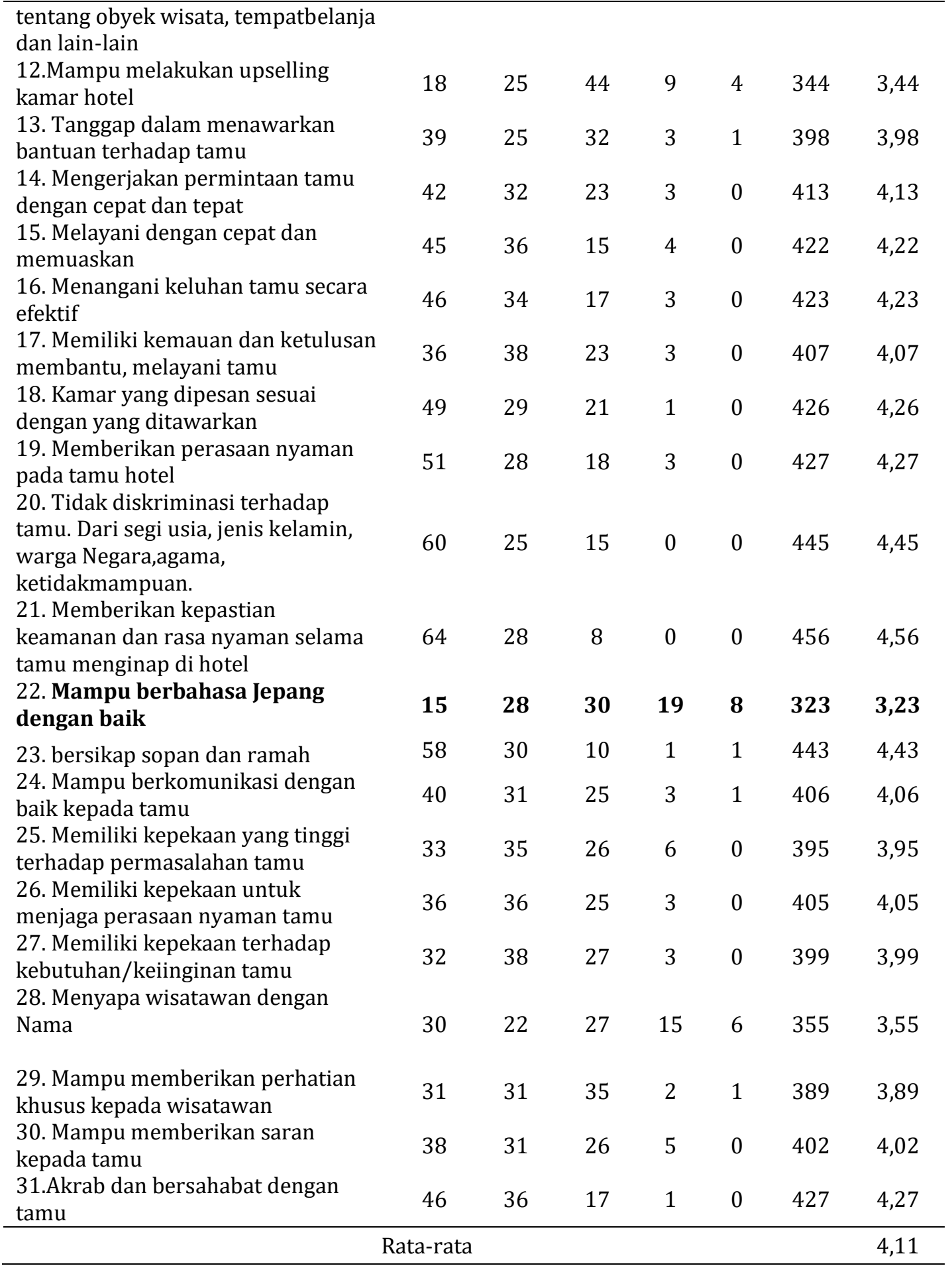

Berdasarkan Tabel 2, terlihat bahwa rata-rata skor dari 31 variabel kualitas pelayanan receptionist yaitu sebesar 4,11 (berada pada kisaran 3,41-4,20) berarti masuk kriteria baik. Walaupun secara umum kualitas pelayanan receptionist masuk kategori baik, namun masih ada penilaian responden dengan kategori sangat kurang baik yaitu pada indikator "kemampuan berbahasa jepang" dengan nilai rata-rata 3,23. 


\subsubsection{Analisis Faktor}

Untuk mengetahui faktor-faktor yang mempengaruhi kualitas pelayanan digunakan analisis faktor Eksploratori, yaitu meringkas variabel-variabel menjadi satu kelompok variabel baru atau faktor. Dari 31 variabel yang mempunyai loading factor $>0,50$, akhirnya terkelompokkan menjadi 7 (tujuh) faktor dan ini menjadi temuan baru sebagai faktor kualitas pelayanan staf front office di Bali.

Dari hasil pengolahan SPSS diketahui 31 variabel mempunyai variasi kumulatif sebesar 73,947\%. Artinya 31 variabel tersebut dapat menjelaskan persentase kepuasan wisatawan Jepang terhadap kualitas pelayanan receptionist hotel sebesar 73,947\%.

Tabel 3: Faktor-Faktor Kualitas Pelayanan Staf Front Office Hotel di Bali

\begin{tabular}{lrrr}
\hline Faktor & Nilai Eigen & \% of Variance & Cumulative \% \\
\hline 1(daya tanggap/responsiveness) & 13,92 & 44,89 & 44,89 \\
2(empati) & 2,36 & 7,60 & 52,49 \\
3(handal/reliability) & 1,51 & 4,88 & 57,37 \\
4(penampilan fisik/tangible) & 1,49 & 4,79 & 62,16 \\
5(bisa dipercaya/assurance) & 1,29 & 4,17 & 66,33 \\
6(ramah/friendly) & 1,22 & 3,94 & 70,27 \\
7(communication) & 1,14 & 3,68 & $\mathbf{7 3 , 9 5}$ \\
\hline
\end{tabular}

Dari tabel di atas terlihat urutan faktor dari nilai eigen value tertinggi hingga terendah. Faktor Daya tanggap (responsiveness) memiliki eigenvalue sebesar 13,916 dan nilai persentase variance sebesar 44,891\%. yang mempengaruhi kepuasan wisatawan Jepang terhadap kualitas pelayanan staf front office hotel di Bali.

Faktor ini dibentuk oleh variabel-variabel (1) memberikan perasaan nyaman pada tamu hotel (P19) dengan loading factor sebesar 0,51, (2) memiliki kepekaan untuk menjaga perasaan nyaman tamu (P26) dengan loading factor sebesar 0,52, (3) memiliki kepekaan terhadap kebutuhan/keiinginan tamu (P27) dengan loading factor sebesar 0,54

, (4) tanggap dalam menawarkan bantuan terhadap tamu(P13) dengan loading factor sebesar 0,63, (5) Kamar yang dipesan sesuai dengan yang ditawarkan (P18) dengan loading factor sebesar $0,64,(6)$ Mengerjakan permintaan tamu dengan cepat dan tepat (P14) dengan loading factor sebesar 0,70, (7) Memiliki kemauan dan ketulusan membantu, melayani tamu (P17) dengan loading factor sebesar 0,74, (8) Menangani keluhan tamu secara efektif (P16) dengan loading factor sebesar 0,76, (9) Melayani dengan cepat dan memuaskan (P15) dengan loading factor sebesar 0,81

Berdasarkan besarnya loading factor , maka variabel" (P15) memiliki pengaruh yang dominan pembentuk faktor Daya Tanggap. Faktor Empati (empathy), faktor ini memiliki eigenvalue sebesar 2,355 dan dengan nilai persentase variance sebesar 7,598\%. Faktor ini dibentuk oleh variabel-variabel (1) Mampu memberikan perhatian khusus kepada wisatawan (P29) dengan loading factor sebesar 0,705, (2) mampu memberikan saran kepada tamu (P30) dengan loading factor sebesar 0,713, (3) akrab dan bersahabat dengan tamu (P31) dengan loading factor sebesar 0,756, (4) menyapa wisatawan dengan Nama (P28) dengan loading factor sebesar 0,80 Berdasarkan besarnya loading factor, variabel (P28) memiliki pengaruh yang dominan pembentuk faktor Empathy.

Faktor Handal (reliability), faktor ini memiliki eigenvalue sebesar 1,513 dan dengan nilai persentase variance sebesar $4,880 \%$. Faktor ini dibentuk oleh variabel-variabel (1) mampu menjelaskan produk hotel, seperti restoran,spa dan lain-lain (P7) dengan loading factor sebesar 0,501, (2) mampu melakukan upselling kamar hotel (P12) dengan loading factor sebesar 0,54, (3) mampu menjelaskan produk kamar hotel (P6) dengan loading 
factor sebesar 0,61, (4) mampu memberikan pelayanan saat check in hotel (P8) dengan loading factor sebesar 0,61, (5) mampu memberikan pelayanan saat check outhotel (P9) dengan loading factor sebesar 0,63 (6) mampu memberikan informasi fasilitas hotel(P10) dengan loading factor sebesar 0,67, (7) mampu memberikan informasi tentang obyek wisata, tempatbelanja dan lain-lain (P11) dengan loading factor sebesar 0,68. Berdasarkan besarnya loading factor, variabel (P11) memiliki pengaruh yang dominan pembentuk faktor Reliability(Handal)

Faktor Penampilan Fisik(tangible), faktor ini memiliki eigenvaluesebesar 1,486 dan dengan nilai persentase variance sebesar 4,792\%. Faktor ini dibentuk oleh variabelvariabel (1) seragam bersih dan menarik (P3) dengan loading factor sebesar 0,66, (2) penampilan bersih dan rapi (P1) dengan loading factor sebesar 0,76, (3) memakai name tag (P2) dengan loading factor sebesar 0,80 . Berdasarkan besarnya loading factor variabel (P2) memiliki pengaruh yang dominan pembentuk faktor Tangibel( tampilan fisik).

Faktor Jaminan (Assurance), faktor ini memiliki eigenvalue sebesar 1,294, dengan nilai persentase variance sebesar 4,173\%. Faktor ini dibentuk oleh variabel-variabel (1) mamar yang dipesan sesuai dengan yang ditawarkan (P18) dengan loading factor sebesar 0,59 , (2) memberikan kepastian keamanan dan rasa nyaman selama tamu menginap di hotel (P21) dengan loading factor sebesar 0,56, (3) bersikap sopan dan ramah (P23) dengan loading factor sebesar 0,63, (4) tidak diskriminasi terhadap tamu. Dari segi usia, jenis kelamin, warga Negara,agama, ketidakmampuan (P20) dengan loading factor sebesar 0,74. Berdasarkan besarnya loading factor, variabel (P20) memiliki pengaruh yang dominan pembentuk faktor Assurance(Jaminan).

Faktor Wajah Tersenyum Ramah(Friendly), faktor ini memiliki eigenvalue sebesar 1,220 dan dengan nilai persentase variance sebesar 3,935\%. Faktor ini dibentuk oleh variabel-variabel (1) Sikap tubuh yang sopan (P5) dengan loading factor sebesar 0,71, (2) wajah selalu tersenyum ramah(P4) dengan loading factor sebesar 0,82. Berdasarkan besarnya loading factor, variabel (P4) memiliki pengaruh yang dominan pembentuk faktor Friendly.

Faktor komunikasi(Communication), faktor ini memiliki eigenvalue sebesar 1,140 dan dengan nilai persentase variance sebesar 3,678\%. Faktor ini dibentuk oleh variabelvariabel (1) memiliki kepekaan yang tinggi terhadap permasalahan tamu (P25) dengan loading factor sebesar 0,57, (2) mampu berkomunikasi dengan baik kepada tamu (P24) dengan loading factor sebesar 0,58, (3) mampu berbahasa Jepang dengan baik (P22) dengan loading factor sebesar 0,70. Berdasarkan besarnya loading factor, (P22) memiliki pengaruh yang dominan pembentuk faktor Communication.

Dengan mengacu pada data diatas diketahui variabel yang dominan mewakili pada setiap faktor adalah sebagai berikut:

1) Faktor Daya tanggap (responsiveness) diwakili oleh variabel "Melayani dengan cepat dan memuaskan"

2) Faktor Empaty diwakili oleh variabel "Menyapa wisatawan dengan menyebut Nama"

3) Faktor Handal(reliability) diwakili oleh variabel "Mampu memberikan informasi tentang obyek wisata, tempat belanja dan lain-lain"

4) Faktor tampilan fisik(tangible) diwakili oleh varaiabel "Memakai name tag"

5) Faktor Jaminan(assurance) diwakili oleh variabel "Tidak diskriminasi terhadap tamu. Dari segi usia, jenis kelamin, warga negara,agama, ketidakmampuan"

6) Faktor Ramah diwakili oleh variabel "Wajah selalu tersenyum ramah"

7) Faktor Komunikasi diwakili oleh variabel "Mampu berbahasa Jepang dengan baik"

\subsection{Pembahasan}

Pelayanan yang memuaskan merupakan kunci penting untuk menjaga keberlangsungan suatu usaha. Pelayanan yang baik akan menarik pelanggan. Dalam teori marketing dikenal dengan $8: 2$, artinya $80 \%$ hasil penjualan, $20 \%$ diperoleh dari 
pelanggan. Untuk itu menjaga kepercayaan pelanggan adalah sangatlah penting. terlebih di dunia pariwisata dimana sikap ramah, menyenangkan dan tulus merupakan unsur penting dalam pelayanan terhadap tamu. Jika menginginkan tamu kembali datang untuk menikmati jasa yang ditawarkan, maka pelaku pariwisata seharusnya selalu menjaga sikap hospitaliti ini. Pelanggan diibaratkan raja. Kesempatan hanya datang satu kali, jadi jangan disia-siakan. "Ichigo Ichie" . artinya "once in a lifetime". Untuk itu pelayanan totalitas, sepenuh hati, dengan tulus iklas dan ramah selalu diberikan kepada konsumen. Di negara Jepang dikenal dengan istilah "omotenashi".

Menurut Montgomery (2016), dalam artikelnya yang berjudul "There is a difference between service and hospitality and it's impacting your asset" bahwa kesan yang diingat tamu bukanlah pelayanan staf hotel, tetapi keramahan yang ditampilkan staf. Sikap ramah dengan senyuman yang tulus dan upaya untuk membuat tamu merasa diterima inilah yang menjadi kesan istimewa bagi tamu, sapaan ramah penuh perhatian seperti tuturan; Mr. XX or Ms. XX, where is home?

Mr. XX or Ms. XX, how was your trip today?

Mr. XX or Ms. XX, have you been at our hotel before?

Can we provide suggestions on where to eat?

Perlu diingat bahwa seorang tamu ingin diakui, dihormati dan dihargai. Untuk itu service saja tidak cukup namun harus dilengkapi dengan sikap ramah, penuh perhatian untuk meninggalkan image istimewa dibenak tamu. Untuk itu sikap-sikap hospitaliti perlu selalu dijaga. Ueda (1997) dalam artikelnya yang berjudul ".Excellent Service Manual. Nihonjinkyaku taisuru Sekkyaku Saabisu ni tsuite." menjelaskan hal-hal yang harus dilakukan petugas hotel dalam memberikan service kepada tamu hotel, seperti:

1) Aisatsu(greeting) $\rightarrow$ Aisatsu berarti berbicara kepada orang lain dengan hati terbuka.

2) Hyoojo( ekspresi wajah) $\rightarrow$ akaruku(wajah nampak senyum tulus penuh keramahan)

3) Itsudemo( selalu) $\rightarrow$ pelayanan yang sama kepada semua tamu tanpa ada pembedaan

4) Sakini( mendahului) $\rightarrow$ Jangan menunggu tamu meminta tolong, tawarkan bantuan atau menanyakan keperluan tamu. Misal nya melihat tamu nampak kesulitan membawa barang, maka staf hotel (bellboy misalnya) dengan sigap menghampiri tamu, menawarkan bnatuan untuk membawakan barangnya.

5) Tsuzukete( berkelanjutan) $\rightarrow$ tetap konsisten dalam pelayanan prima, tidak mengenal kata lelah, selalu menunjukkan profesionalisme kerja.

6) Midashinami(keindahan dalam dan luar) $\rightarrow$ yaitu kerapian fisik (berseragam, rambut rapi) dan kecantikan hati

7) Taido(sikap) $\rightarrow$ yaitu semangat, tulus, kreatif

8) Kotobazukai ( cara berbicara) $\rightarrow$ menggunakan bahasa yang sopan( keigo)

9) Ojigi (bowing)sebagai ekspresi hormat

10) Tidak saling bicarasaat bekerja, apalagi ngobrol. Perhatian sepenuhnya hanya untuk pelanggan. Jika berbicara dengan rekan kerja terkait urusan pekerjaan, mereka menjaga untuk tidak bersuara keras.

11) Tidak makan saat kerja. Suatu hal yang sangat tidak sopan, jika terlihat makan didepan tamu(konsumen).

12) Dari dalam hati adanya keinginan untuk memberikan pelayanan yang tulus

Dengan melihat hasil analisis data didapatkan gambaran bahwa kualitas pelayanan staf front office hotel di Bali tergolong baik dengan nilai rata-rata sebesar 4,11. Namun masih terdapat penilain rendah pada variabel kemampuan berbahasa Jepang, dengan nilai ratarata 3,23 .

Dari hasil analisis faktor, ditemukan tujuh faktor yang mempengaruhi kualitas pelayan staf front office hotel, yaitu faktor: 1) responsiveness dengan nilai $(13,916), 2)$ empathy (2,355), 3) reliability (1,513), 4) tangible $(1,486), 5)$ assurance $(1,29), 6)$ friendly 
$(1,220)$, dan 7) communication $(1,140)$. Hdari tujuh faktor tersebut, terlihat bahwa faktor Daya tanggap (responsiveness) memiliki nilai tertinggi, sedangkan faktor terendah adalah faktor komunikasi (communication).

Daya tanggap (responsiveness) merupakan faktor yang mendapat penilaian tertinggi, sikap "melayani tamu dengan cepat dan memuaskan". Suatu hal yang sangat membanggakan, sikap ini mendapat penilaian tertinggi. Urutan kedua adalah faktor Empaty, seperti menyapa tamu dengan memanggil nama tamu, sehingga tamu merasa diperlakukan istimewa. Hal ini memberikan cerminan bahwa gaya pelayanan staf hotel di Bali menonjol pada dua faktor ini yakni responsiveness dan empaty. Kedua sikap ini harus terus dipertahankan. Faktor-faktor lain yang mendapatkan nilai rendah, harus terus ditingkatkan, kususnya di faktor komunikasi dalam berbahasa Jepang. Kemampuan berbahasa Jepang pelaku pariwisata baik verbal maupun nonverbal perlu ditingkatkan. Pelayanan tidak lepas dari ketrampilan berkomunikasi. Komunikasi tidak hanya menyampakan suatu pesan, namun cara, sikap dalam menyampaikan pesan mempengaruhi nilai dari suatu kualitas pelayanan. Ketrampilan berbahasa dan sikap merupakan perpaduan yang saling melengkapi untuk mewujudkan sikap pelayanan prima.

Disinilah pentingnya jiwa omotenashi dalam setiap pelayanan sehingga tamu merasa senang, puas dan akhirnya terkesan dengan liburannya. Kesan yang baik ini memberikan dampak positif terhadap industri perhotelan. Wisatawan akan melakukan kunjungan ulang dan dengan senang hati merekomendasikan kepada teman, kerabat atau orang lain lewat media sosial yang dampak jangkaunnya lebih luas. Review positif dari tamu, akan memberikan dampak besar bagi hotel. Calon-calon tamu akan memperhatikan review dari tamu yang sudah pernah menginap. Jika tamu memberikan review positif, maka secara tidak langsung citra hotel ikut naik dan akan menarik calon-calon tamu untuk menginap.

\section{KESIMPULAN}

Hasil temuan penelitian ini diketahui bahwa kualitas pelayanan staf front office hotel di Bali mendapat penilaian "baik" dengan nilai rata-rata sebesar 4,11. Namun demikian masih terdapat variabel yang mendapatkan penilaian rendah, yaitu variabel kemampuan berbahasa Jepang, dengan nilai rata-rata 3,23.

Dari hasil analisis faktor eksploratori, ditemukan tujuh faktor pembentuk kualitas pelayanan staf front office hotel di Bali. Faktor tertinggi adalah responsiveness dengan nilai $(13,916)$, ke- 2 adalah empathy $(2,355)$, ke-3 reliability $(1,513)$, ke- 4 tangible $(1,486)$, ke-5 assurance $(1,29)$, ke-6 friendly $(1,220)$, dan terendah adalah faktor communication $(1,140)$ Oleh sebab itu faktor komunikasi ini harus mendapatkan perhatian. Suatu pelayanan tidak bisa dilepaskan dari ketrampilan berkomunikasi. Kemampuan berbahasa Jepang petugas fronf office masih tergolong rendah. Untuk itu kedua point kelemahan tersebut perlu selalu ditingkatkan demi menjaga kualitas pelayanan yang memuaskan tamu. Sebagai saran terhadap pihak hotel, perlu diadakannya pelatihan bahasa Jepang kususnya terhadap staf kantor depan dimana staf kantor depan lebih banyak bertatap muka dengan tamu dibandingkan staf di departemen lain. Bahkan diibaratkan bahwa kinerja staf kantor depan bisa mewakili wajah hotel. jika pelayananya menyenangkan dan memuaskan tamu maka citra hotel ikut terangkat. Begitu pula sebaliknya. sehingga pelayanan di kantor depan perlu selalu dijaga kualitasnya demi menjaga citra hotel.

\section{PERNYATAAN PENGHARGAAN}

Terimakasih kepada manajemen Politeknik Pariwisata Bali atas bantuan pendanaan penelitian tentang kualitas pelayanan staf front office hotel di Bali sehingga dapat dihasilkan artikel jurnal ilmiah. 
Indah Kusumarini

\section{DAFTAR PUSTAKA}

A.Parasuraman, Zeithaml and Berry.(1988) SERVQUAL; A Multiple-Item Scale for Measuring Consumer Perceptions of Service Quality. Journal of Retailing. Vol 64(1) pp.12-37

Alan. Y (2016). Pengaruh Service Quality(Tangible, Empathy, Reliability, Responsivenessdan Assurance) terhadap Customer Satisfaction di Hotel Serela Bandung. Jurnal Manajemen Maranatha, 15(2) diakses dari https: // doi. org / 10.28932/jmm.v152,18

Arief,Mts.(2005).Pemasaran Dan KualitasPelayanan.Malang.Bayumedia Publishing.

Badan Pusat Statistik Provinsi Bali.(2018).Number of Foreign Visitors Arriving directly by Nationality to Bali 2014-2018. Badan Pusat Statistik Provinsi Bali. Diakses dari https:// bali.bps. go.id /statictable/2018/02/09/27/jumlah-wisatawanmancanegara-yang-datang-langsung-ke-bali-menurut-kebangsaan-2014-2018.html)

Bagyono. (2012). Teori dan Praktek Hotel Front Office. Bandung: Penerbit Alfabeta.

John. A. (2016). Service and hospitality:There's a differenceanditimpactsyourasset. Diakses dari https://www.hotelmanagement.net/guest-relations/there-differencebetween-service-and-hospitality-and-its-impacting-your-asset?

Kotler,P.(2013).Manajemen Pemasaran di Indonesia: Analisis, Perencanaan, Implementasi dan Pengendalian. SalembaEmpat. Jakarta.

Nurhidayah, B. (2017) .Kualitas pelayanan Front Office Departement Syariah Hotel Solo Terhadap Tingkat Kepuasan Tamu Individual. Diakses dari https://fud.iainsurakarta.ac.id/akasia/ index.php?p= show_detail \&id =1597 \&keywords=

Rahma, S. ( 2019). Naik Signifikan Daya Saing Indonesia di Posisi 32 Dunia. Diakses dari https://www.google.com/amp/s/amp.kompas.com/ money/ read/ 2019/05/29/140135526/naik-signifikan-daya-saing-indonesia-di-posisi-32-dunia

Riduwan.(2010).Dasar-Dasar Statistik, Cet.4. Bandung:Alfabeta

Sedarmayanti. (2006). MetodologiPenelitian.Bandung: Mandar Maju

Soenarno.(2006).Peranan dan Fungsi Receptionist.Yogyakarta.Graha Ilmu

Sudjana.(2007).Statistika untuk Ekonomi dan Niaga. Bandung: Tarsito

Tjiptono, F (1996). Strategi Pemasaran. Andi Offset.Yogyakarta.

Ueda.S.(1997).Excellent Service Manual. Nihonjin kyaku taisuru Sekkyaku Saabisu ni tsuite. JICA.Jakarta 